\title{
공공도서관 $\mathrm{OPAC}$ 인터페이스의 발전방안 연구
}

\section{A Study on the Development Plan of Public Library OPAC Interface}

\author{
하 은 아 (Eun-Ah Ha)* \\ 이 성 숙 (Sung-Sook Lee)**
}

\begin{abstract}
초 록
이 연구의 목적은 공공도서관 $\mathrm{OPAC}$ 인터페이스의 발전방안을 제안하기 위한 것이며, 이를 위해 국내 - 외 공공도서관 $\mathrm{OPAC}$ 인터페이스의 사례를 분석하고, $\mathrm{OPAC}$ 인터페이스에 대한 이용자 요구를 조사하기 위하여 $\mathrm{OPAC}$ 의 이용행태, 기능요구도, 개선사항을 중심으로 설문조사를 실시하였다. 공공도서관 $\mathrm{OPAC}$ 인터페이스 는 인터페이스 설계 원칙을 준수하며 이용자 요구를 반영하여 설계되어야 한다. 이를 위해 자료에 대한 완전한 서지 레코드를 입력하여 $\mathrm{OPAC}$ 의 다양한 기능 구현을 위한 기반을 제공해야 한다. 이 연구 결과는 공공도서관 $\mathrm{OPAC}$ 인터페이스의 설계에 기초자료로 활용될 수 있을 것이다.
\end{abstract}

\section{ABSTRACT}

The aim of this study is to propose a development plan of public library OPAC interface. For this purpose, the study analyzed cases of OPAC interface of domestic and overseas public libraries, and took a questionnaire survey on use types, level of functional demand and improvement matters of OPAC in order to examine the user requirements on OPAC interface. Public library OPAC interface must comply with interface design principle and reflect requirements of users. Accordingly, it must supply foundation to realize various OPAC functions by inputting perfect bibliographic records on resources. The research result could be used as basic resources for the public library OPAC interface design.

키워드: 공공도서관, 온라인열람목록, 차세대목록, 인터페이스

Public Library, OPAC, OPAC 2.0, Catalog 2.0, Next-generation Catalog, Interface

* 충청북도 중앙도서관 사서(tomatoblue@cbe.go.kr) (제1저자)

** 충남대학교 문헌정보학과 부교수(infolee@cnu.ac.kr) (교신저자)

논문접수일자 : 2013년 5월 15일 논문심사일자 : 2013년 5월 27일 게재확정일자 : 2013년 6월 20일 


\section{1. 서 론}

\section{1 연구 필요성 및 목적}

온라인열람목록(Online Public Access Cata$\log$ : 이하 $\mathrm{OPAC}$ )의 사전적 정의는 "단말기를 통해 검색할 수 있도록 컴퓨터로 운영되는 도서 관목록”으로(한국도서관협회 2010), 도서관 이 용자는 $\mathrm{OPAC}$ 을 이용한 검색 및 브라우징을 통 해 직접 서지정보를 탐색할 수 있다. 전통적으 로 $\mathrm{OPAC}$ 은 도서관 자료와 이용자를 연결해 주 는 중요한 역할을 해왔다.

인터넷과 웹의 활성화는 이용자의 도서관 이용 행태에 변화를 가져왔으며, 이용자는 정보 검색 의 시작점으로 도서관 $\mathrm{OPAC}$ 보다 구글(Google) 과 같은 검색 포털엔진이나 온라인 서점을 선 호하고 있다. Pace(2007)는 현재의 OPAC은 이미 알려진 자료는 쉽게 검색할 수 있지만, 키 워드 검색은 너무 많거나 적은 검색결과를 표 시해 이용자로부터 신뢰를 받지 못하고, 이용자 는 전거에 대한 이해가 부족하며, 토픽 검색과 주제 접근이 어렵고, 장서 브라우징이 불가능하 며, 시스템에서 적합성에 의한 검색 결과를 제 공하지 않고, 검색어 철자 오류 수정이 어렵고, 검색 응답시간이 만족스럽지 않고, 서지정보에 포함된 요소는 풍부하지만 제대로 이용되지 않 고 있다고 지적하였다.

이와 같은 $\mathrm{OPAC}$ 의 위기와 함께 변화요구 에 힘입어 목록도 최근 몇 년 사이 이용자 중심 의 서비스 제공을 위한 참여, 공유, 개방, 소통 을 중심으로 하는 Web 2.0 관련 기능들을 포함 하기 시작했는데 이를 $\mathrm{OPAC} 2.0$ 이라고 한다. $\mathrm{OPAC} 2.0$ 은 차세대목록, 제 3 세대목록, 21 세기
목록, Catalog 2.0이라는 용어와 혼용되어 사용 되고 있다. OPAC 2.0 의 대표적 기능은 인터페 이스의 개선부터 서비스 방법 개발, 이용자가 참여하는 소셜네트워킹 활동 등이며, 그 구체적 인 예는 적합성 순위(Relevance Ranking), 검 색어 자동완성 및 스펠링 체크 기능, 간결한 검 색창('구글 형식 검색'), 패싯 기능, 유사자료 검 색기능, 이용자 생산 정보 RSS 기능 등이다(국 립중앙도서관 도서관연구소 2011).

국내에서도 대학도서관을 중심으로 이러한 $\mathrm{OPAC} 2.0$ 의 기능을 선별하여 적용하고 있다. 국내 일부 공공도서관에서도 최근 $\mathrm{OPAC} 2.0$ 기능을 적용하여 링킹사이트, 목차 및 저자 정 보 등의 풍부한 콘텐츠 등의 기능적인 측면을 개선한 $\mathrm{OPAC}$ 인터페이스를 제공하고 있지만, 대다수 도서관은 아직도 자관의 소장 자료 유 무만을 파악할 수 있는 정도와 간단한 서지사 항을 제공하고 있다. 이에 공공도서관 $\mathrm{OPAC}$ 인터페이스도 OPAC 2.0 기능을 검토하고, 이 용자의 요구에 부합하여 보다 이용자 친화적인 $\mathrm{OPAC}$ 인터페이스 설계 방안을 고민할 필요가 있다.

이 연구의 목적은 공공도서관 $\mathrm{OPAC}$ 인터 페이스 발전방안을 제안하기 위한 것이며, 이를 위해 국내 - 외 공공도서관 $\mathrm{OPAC}$ 인터페이스 의 사례를 분석하고, $\mathrm{OPAC}$ 인터페이스에 대 한 이용자 요구를 조사하기 위하여 $\mathrm{OPAC}$ 의 이 용행태, 기능요구도, 개선사항을 중심으로 설문 조사를 실시하였다. 이 연구결과는 공공도서관 $\mathrm{OPAC}$ 인터페이스 설계의 기초자료로 활용될 수 있을 것이다. 


\section{2 선행연구}

선행연구는 OPAC 2.0에 대한 이론 및 사례 연구, OPAC 2.0 기능의 이용자 선호도에 대한 연구, 공공도서관 인터페이스에 대한 연구로 구 분하여 살펴보았다. OPAC 2.0 은 차세대 목록, Catalog 2.0 등의 용어로도 표현되기 때문에 그 와 관련된 선행연구도 살펴보았다.

먼저 OPAC 2.0에 대한 이론 및 사례연구에 대해 살펴보면, 구중억과 이응봉(2006)은 Web 2.0과 Library 2.0, OPAC 2.0에 관한 정의 및 개념, 관련 웹 기술, 그리고 국내 - 외 웹 포털 및 도서관 적용사례를 조사 분석하고, $\mathrm{OPAC}$ 검색결과 및 검색서비스의 향상을 위한 $\mathrm{OPAC}$ 2.0 서비스에 적용할 수 있는 하나의 방법으로써 Open API 및 RSS 리더를 구현하고 구체적인 활용방안을 제시하였다. 구중억과 곽승진(2007) 은 국내 도서관 소프트웨어와 이 소프트웨어의 인터페이스를 검색창, 검색항목, 검색기법, 정렬 기능, 검색결과디스플레이, 검색결과 피드백에 중점을 두어 조사하고, 차세대 $\mathrm{OPAC}$ 인터페이 스, 검색 기능, 도서관 2.0 서비스 측면에의 구체 적 사례를 분석한 후, 국내 도서관 $\mathrm{OPAC}$ 인터 페이스와 기능의 개선방안을 제시하였다. 심경 (2008a/2008b/2008c)은 차세대 도서관 목록에 대한 개념을 제공하고 모든 기능을 일괄적으로 도서관에 적용할 필요는 없으나 이용자 만족을 위해서 개별 도서관의 예산과 환경에 따라 단계 별로 추진하는 것도 최소한의 노력이라고 권고 하고 있다. 윤정옥(2010)은 차세대 멜빌 파일로 트(Next-generation Melvyl Pilot)와 서치워크 (SearchWorks)의 사례비교에서 이용자 편의성 과 접근성을 반영한 기능이 어떻게 구현되는지
분석하고, 국내 도서관에서 차세대 목록을 구축 하기 위하여 기반을 고르는 작업이 필요함을 제 안하였다. 이지원(2010)은 차세대목록 인터페 이스와 OPAC 2.0 의 기능을 밝히고, OCLC의 구체적 사례를 분석하여 웹 이용자 서비스를 중 심으로 서지 네트워크의 발전 방향을 개방전략, 연계전략, 동질화/차별화 전략으로 나누어 제시 하였다. 유영준(2011)은 자원 발견 인터페이스 를 도입하고 사용하고 있는 국내 - 외 9개 도서 관의 사례를 분석하여, 패싯 용어 선정에 있어 일관성 있는 구성이 필요함을 주장하였다. 또한 윤정옥(2012)은 차세대 목록에서 이용자 서평 기능의 이용 현황 및 서지레코드에서 연결될 수 있는 외부 정보원의 이용자 서평의 영향 가능성 을 살펴보고, 이용자 서평 사례 분석을 통해서 이용자 참여 기능이 왜곡될 수 있는 가능성을 암시하였으며, 이를 위해 제도적 장치를 마련할 필요가 있음을 밝혔다. 이현실(2010)은 웹 2.0 실현 도구로 간단한 검색 도구인 도서관 $\mathrm{OPAC}$ 툴바를 제공하여 인터넷 툴바와 비교평가하고, $\mathrm{OPAC}$ 이 인터넷과 같이 편리하고 유용하게 사 용될 수 있는 검색도구임을 규명하였다.

OPAC 2.0 기능에 대한 이용자 선호도 연구 로 김예린(2012)은 OPAC 2.0 기능 중요도에 대한 이용자 설문조사를 실시하고 문헌에서 강 조되는 $\mathrm{OPAC} 2.0$ 의 기능과 비교 분석한 후, 대 학도서관의 OPAC 2.0 기능 평가 체크리스트를 개발하였다. 이혜영(2012)은 OPAC 2.0 서비스 에 대한 이용자 인식을 조사하여, 이용자들의 의 견이 고려된 OPAC 2.0 서비스의 개선이 필요 함을 강조하고, 대학도서관 OPAC 2.0 서비스 를 위한 기초자료를 제공하였다.

다음으로 공공도서관 $\mathrm{OPAC}$ 인터페이스 관 
련 선행연구로 김선호(2003)는 노인 인구의 증 가에 따라 공공도서관의 노인 서비스에 관한 책 임을 논하며, 노인용 인터페이스와 관련하여 웹 페이지 개발에 필요한 디자인 요소와 내용을 분 석하였다. 윤정옥(2006)은 공공도서관 어린이 용 $\mathrm{OPAC}$ 디스플레이를 분석하여, 어린이청소 년 자료를 검색하는 이용자의 정보요구와 형태 를 반영한 $\mathrm{OPAC}$ 디스플레이가 구축되어야 함 을 언급하였다. 김혜주(2007)는 국내 어린이 도 서관의 검색 인터페이스 디자인을 조사하고 문 제점을 개선하기 위한 방안으로 이용자 집단의 특성을 반영하여 디자인되어야 되고, 검색 인터 페이스의 경우 디자인 단계에서 이용 대상자를 참여시켜 눈높이에 맞는 인터페이스를 디자인 해야 한다고 밝혔다. 사공복희(2012)는 어린이 도서관 온라인 목록의 인터페이스 7 가지 유형 을 분석하여 문제점을 진단하고 시스템의 개선 및 새로운 시스템 설계 시 고려해야 할 방향을 제시하였다. 그러나 지금까지의 선행연구 분석 에서 알 수 있듯이 공공도서관 이용자의 $\mathrm{OPAC}$ 인식에 대한 연구 및 인터페이스에 대한 연구는 미비한 실정이다.

\section{3 연구방법}

이 연구의 연구방법은 사례분석과 설문조사 로 이루어졌고, 구체적인 방법을 살펴보면 다음
과 같다.

\subsection{1 공공도서관 $\mathrm{OPAC}$ 인터페이스 사례 분석}

국가통계시스템(2011)에 따르면, 국내 공공도 서관은 공공도서관(일반) 725개, 공공(어린이) 도서관 79 개, 문고를 포함한 작은 도서관은 3,417 개로 총 4,221개의 도서관이 운영 중이다. 각각의 공공도서관은 KOLAS III, SLIMA, KOLASYS 등의 다양한 소프트웨어를 사용하며, 사용하는 소프트웨어에서 제공하는 $\mathrm{OPAC}$ 인터페이스를 이용자에게 제공하고 있다. 또한 2009년 도서관 법 개정에 따라 지정된 몇몇 지역대표도서관은 그 지역의 상이한 $\mathrm{OPAC}$ 인터페이스를 통합한 인터페이스를 구축하여 운영하고 있다.

이 연구의 분석대상으로는 국내 공공도서관 에서 사용되고 있는 소프트웨어인 KOLAS III, DLS(Digital Library Search), GOLDIS-NET, SLIMA, DJHLS를 선정하였다.1) 또한 국외는 Breeding(2012)의 자료 중 2009년에서 2011년 동안 3년간 판매 실적 중에서 ILS를 위한 공공 도서관의 목록 시스템 판매율2) 상위 5 개를 선 택하여, Polaris ILS, Symphony, Apollo, Koha, LS2PAC를 분석하였다. ${ }^{3)}$

선정된 사례의 인터페이스 분석 기준은 선행 연구(채현수, 이지연 2012)에서 제시된 이용자 인터페이스 설계원칙을 사용하였다. 이 연구에

1) KOLASIII : 충청북도중앙도서관, DLS: 전북도청도서관, GOLDIS-NET: 경기도사이버도서관, SLIMA: 청주 시립도서관, DJHLS: 대전한밭도서관의 인터페이스로 특정한 명칭이 없어 연구자가 임의로 명명함.

2) Symphony의 '09년부터 ' 11 년 누적 판매량은 248건이며 '11년 판매량은 121 건이다. Apollo는 누적 판매량이 221 건 ' 11 년 판매량은 79 건이다. Polaris ILS의 누적판매량은 109 건이며 ' 11 년 판매량은 53 건이다. Koha와 LS2PAC 의 누적판매량은 각 105 건, 121 건이며, ' 11 년 판매량은 각 54 건, 48 건이다.

3) Symphony: County of Los angeles Public Library, Apollo: Vinta Public Library, Polaris ILS: Henderson Library, Koha: Columbia County rural Library District, LS2 PAC: LA Public Library. 
서 사용된 이용자 인터페이스 설계원칙은 '일관 성', '관용성', '직관성', '실생활관행', '적합성', '시스템 피드백', '도움말', '가시성', '내비게이 션', '학습용이성', '이용수준' 등이며, 제외된 설 계원칙은 '이용성평가'와 '모드설계', '대안선택' 등이다.

한편 이 연구에서는 인터페이스 설계원칙에 따라 OPAC 2.0 의 주요 기능을 범주화하였다. $\mathrm{OPAC} 2.0$ 기능에 대해 여러 문헌에서 다양한 기능이 언급되었지만, 이 연구에서는 OPAC 2.0 기능으로 검색어자동완성, 철자오류수정, 관 련자료 추천, 태그 클라우드, 적합성순 정렬, 개인맞춤화, 패싯 내비게이션, 풍부한 콘텐츠, 링킹사이트, 이용자 참여, 소셜 네트워크, 실시 간 정보제공, 시선추적 페이지, 매쉬업, 위젯을 중심으로 검토하였다. $\mathrm{OPAC}$ 의 기능은 인터 페이스 설계원칙에 있어 '관용성', '직관성', '적 합성, '가시성', '내비게이션'의 원칙으로 범주 화할 수 있었으며, 구체적으로 인터페이스 설 계원칙 '관용성'에는 OPAC 2.0 기능 중 검색어 자동완성, 철자 오류 수정, 관련자료 추천, 태그 클라우드가 해당하며, '직관성'에는 위젯, '적합 성'에는 적합성순 정렬, 개인맞춤화, '가시성'에 는 풍부한 콘텐츠 링킹사이트 소셜네트워크 이 용자참여, 시선추적, 매쉬업, 실시간 정보제공, ‘내비게이션'에는 패싯 내비게이션 기능이 해당 된다.

\subsection{2 이용자 요구도 설문조사}

질문지는 총 32 개 세부 문항으로 구성되었고, 질문지 구성을 위해 유재옥(2000), 김태승과 이 동규(2005), 사공복희(2012), 이혜영(2012) 등 의 선행연구를 참고하였다. 질문지에는 응답자
의 이해를 돕기 위하여 'OPAC'에 대해 간단히 설명하고, $\mathrm{OPAC}$ 기능에 대한 설명 자료를 기 술하였다. 또한 인구통계학적 특성에 관한 문 항으로 이용자와 사서를 구분하는 문항과 성별 과 연령에 관한 문항을 구성하였다. 다음으로 도서관 $\mathrm{OPAC}$ 에 대한 인식을 파악하기 위하여 $\mathrm{OPAC}$ 의 이용빈도, 사용 목적, 검색 시 사용하 는 용어를 문항으로 구성하였으며, OPAC 인터 페이스 만족도 및 난이도 등과 관련하여 화면구 성의 만족도, 검색 결과 정보의 만족도, 검색의 난이도, 충분한 키워드 제공, 주제어 제공, 목차 등과 같은 정보 제공의 만족도 문항을 리커트 5점 척도형으로 구성하였다.

$\mathrm{OPAC} 2.0$ 의 기능에 관련한 문항으로 $\mathrm{OPAC}$ 2.0 의 기능에 대한 필요도를 질문하였고 $\mathrm{OPAC}$ 인터페이스 개선 관련 문항으로는 인터페이스 설계원칙의 이용자수준, 도움말, 학습용이성, 개 인화, 실생활 관련하여 생활용어의 사용에 관련 한 문항으로 구성하였으며, $\mathrm{OPAC}$ 인터페이스 개선되기 위한 필수사항을 묻는 문항을 추가하 였다.

질문지 배부 및 회수는 2012년 11월 29일부 터 12 월 2 일까지 4 일간 진행하였다. 설문 조사 는 KOLASIII 인터페이스를 이용한 경험이 있 는 이용자를 대상으로 실시하였다. 설문대상 이 용자는 $\mathrm{OPAC}$ 인터페이스에 쓰여진 언어적 의 미를 이해하고, 인터넷 검색 및 컴퓨터 활용이 능숙한 이용자층인 성인(10대 후반 50대)으 로 한정시켜 실시하였다. 컴퓨터 활용에 익숙하 지 않은 노인 계층은 요구조사에서 제외하였다. $\mathrm{C}$ 지역 공공도서관 이용자들을 임의로 선정하여 직접 대면 설문조사를 실시하였다. 전문가 설문 조사는 KOLAS III를 사용하고 있는 C지역 공 
공도서관 사서 및 기타 지역 공공도서관 사서 를 대상으로 실시하였다.

질문지 배부 및 회수 결과 질문지 178 부를 회 수하였으며, 이 중 문항에 대한 응답 누락으로 결과 분석에 부적당한 4 부를 제외하고 총 174 부 를 분석하였다. 수집된 자료의 통계처리를 위하 여 SPSS19.0과 EXCEL 2010을 이용하였다. 그 리고 자료에 대한 전체적이고 일반적인 경향을 알아보기 위하여 빈도분석(Frequency Analysis) 을 실시하였으며 각 변수의 평균과 표준편 차 등이 필요한 부분에는 기술통계(Descriptive Statistics)를 실시하여 수집된 데이터의 기술 적 특성을 살펴보았다. 다중 응답을 요청한 문항 은 범주형 다중 응답 빈도분석법을 사용하여 빈 도를 측정하였으며, 이용자별 및 이용자와 사서 간 집단간의 차이를 분석하기 위해서 $\mathrm{t}$-검증과 아노바검증 $(\mathrm{F}-$ 검증 $)$ 을 실시하였다. 설문문항 에 대한 신뢰도는 크론바흐알파계수(Cronbach's Alpha) 0.713 으로 나타나 바람직한 것으로 판 단되었다.

\section{2. 이론적 배경}

OPAC은 80년대를 거치면서 컴퓨터 기술의 발달과 정보검색 기법들이 개발됨에 따라 전통 적으로 이루어져 왔던 저자명, 서명, 주제명 등 의 주로 특정의 알고 있는 항목(known item) 에 의한 검색방식으로부터 키워드의 이용, 불리 언의 논리 등의 후조합 탐색방식 사용으로 그 기능이 점점 다양화되었다. 이처럼 $\mathrm{OPAC}$ 은 전 통적 열람목록의 기능을 넘어 이용자가 직접 접 근하여 원하는 정보를 탐색할 수 있는 다양한
탐색 기능을 갖춘 온라인 목록이 되었다(남태 우, 김창하 2007).

인터넷과 웹 기술의 발전은 $\mathrm{OPAC}$ 의 기능적 변화와 인터페이스에 또 다른 변화를 가져오고 있다. OPAC은 OPAC 2.0 으로 변화하고 있는 데, OPAC 2.0은 차세대목록, 제 3 세대목록, 21 세기목록, Catalog 2.0이라는 용어와 혼용되어 사용되고 있지만(Wilson 2007), OPAC 2.0 의 개념에 대한 공통된 의견이 아직 없다.

이러한 사실은 차세대 도서관 목록에 대한 한 연구(윤정옥 2010)에서 확인할 수 있다. 차세대 도서관 목록은 무엇인가에 대해서 도서관계에서 완전히 의견이 통일되지는 않았다고 할 수 있다. 대부분 차세대 도서관 목록이 전통적인 통합 도 서관 시스템을 넘어서서, 기능적인 면에서 보다 강력한 대안을 제시함으로써 기존 $\mathrm{OPAC}$ 을 대 체하거나 업그레이드 하려는 노력의 산물이라 는 점에는 동의한다. 다른 연구(심경 2008a)에 서도 차세대 도서관 목록은 이전부터 기존 도서 관 목록이 가지고 있던 장점, 즉 소장자료의 정 교하고 정확한 발견 및 위치정보 제공이라는 기 능에 일반 웹에서 제공되는 새로운 인터페이스 기능성을 통합하여 변화하는 이용자 요구수준 에 근접하려는 의도로 시작된 것임을 강조한 바 있다. 그런 맥락에서 차세대 도서관 목록은 사 실상 서지목록 자체가 아니라 인터페이스이고 툴이며, 기술적 측면으로는 데이터베이스와 색 인의 조합이라고 하였다.

차세대 도서관 목록을 어떻게 정의하든, 혹은 어떤 제품을 사용하든 중요한 점은 현재 도서관 $\mathrm{OPAC}$ 의 기능성을 개선하여, 보다 이용자 친화 적이며 직관적으로 이해할 수 있고, 미적으로도 끌리는 인터페이스를 제공하며, 구글과 같은 서 
〈표 1〉문헌별 OPAC 2.0 기능

\begin{tabular}{|c|c|}
\hline 문헌 & 세부 기능 항목 \\
\hline $\begin{array}{l}\text { Breeding } \\
(2007)\end{array}$ & $\begin{array}{l}\text { 풍부한 콘텐츠, 패싯 내비게이션, 키워드 검색, 적합성, 이것을 의미하셨습니까?, 추천기능, 이용자 } \\
\text { 참여, RSS }\end{array}$ \\
\hline $\begin{array}{l}\text { Pattern } \\
(2007)\end{array}$ & $\begin{array}{l}\text { 어디에서나 이용 가능한 } \mathrm{OPAC} \text {, 검색어 제안, 풍부한 콘텐츠, } \mathrm{RSS} \text { 피드, 패싯/패싯화된 브라우징, } \\
\text { 추천자료, 이용자 코멘트, 서평추가, 이용자 태그 추가, 개인화된 제안, 이용자 평점 추가 }\end{array}$ \\
\hline $\begin{array}{l}\text { Wilson } \\
(2007)\end{array}$ & $\begin{array}{l}\text { 적합성, 태그 맵/클라우드 클러스터링, 패싯, 확장된 검색 결과, 추가적인 검색 제안, 각 정보원으로부 } \\
\text { 터의 데이터 색인, 철자 교정, 커뮤니티/이용자 리뷰 또는 태그 }\end{array}$ \\
\hline $\begin{array}{l}\text { Chalon 등 } \\
\text { (2008) }\end{array}$ & $\begin{array}{l}\text { 이용자 코멘트, 이용자 평점, 이용자 태그, 대출 기반 자료 추천, } \mathrm{API} \text {, 이메일이나 RSS를 이용한 } \\
\mathrm{SDI} \text { 서비스, 패싯 검색, 철자 제안, 저자 기반 자료 추천 }\end{array}$ \\
\hline $\begin{array}{l}\text { Marcin 과 Morris } \\
\text { (2008) }\end{array}$ & $\begin{array}{l}\text { 이것을 의미하셨습니까?, 성격별 결과 분류, 태그 클라우드, 관련 자료 추천, 고급 검색, 결과 } \\
\text { 리스트에서 바로 이용 가능한 자료의 소장정보, 기록 내보내기 및 인쇄, 통합 검색, 다른 사이트나 } \\
\text { 서비스로의 쉬운 접근, 이용자 평점, 태그, 리뷰, 주요 ILS와의 통합, 기술이나 목록담당 직원을 } \\
\text { 위한 레코드 업로딩의 이용, 개인맞춤화, 미국장애인법(ADA) }\end{array}$ \\
\hline $\begin{array}{l}\text { Tam 등 } \\
(2009)\end{array}$ & $\begin{array}{l}\text { 패싯 브라우저, 적합성순위, 추천기능, 철자 검사, 북자켓, 내용 목차/요약, 코멘트\&평점, RSS, } \\
\text { 브라우징 제안, 태그 클라우드 }\end{array}$ \\
\hline $\begin{array}{l}\text { Yang 과 Hofmann } \\
\text { (2011) }\end{array}$ & $\begin{array}{l}\text { 모든 도서관 정보원에 대한 단일 접근법, 최신의 웹 인터페이스, 풍부한 콘텐츠, 패싯 내비게이션, } \\
\text { 간단한 키워드 검색창, 적합성, 이것을 의미하셨습니까?, 추천기능, 이용자 참여, RSS, 소셜 네트워킹 } \\
\text { 사이트와의 연계, 지속적인 링크 }\end{array}$ \\
\hline $\begin{array}{l}\text { 구중억과 곽승진 } \\
\text { (2007) }\end{array}$ & $\begin{array}{l}\text { 검색창(간단 검색창/빠른 검색), 검색어 자동완성, 철자 오류 자동수정, 이것을 의미하셨습니까?, } \\
\text { 시선추적을 통한 검색 결과 페이지 구성, 통합 검색, 패싯 브라우징, 적합성 정렬, 클러스터링, } \\
\text { 시각화, RSS, AJAX 기반 실시간 정보제공, 위젯, 이용자 참여, SOPAC, 오픈 서치 플러그인, } \\
\text { 서비스형 } \mathrm{S} / \mathrm{W}, \mathrm{SNS}, \text { 소셜 북마크, 매쉬업 서비스 }\end{array}$ \\
\hline $\begin{array}{l}\text { 도서관용어해설 } \\
\quad(2011)\end{array}$ & $\begin{array}{l}\text { 적합성, 검색어 자동완성, 스펠링 체크, 간결한 검색창, 패싯 기능, 원문 검색, 유사자료 검색기능, } \\
\text { 이용자 생산 정보, RSS }\end{array}$ \\
\hline
\end{tabular}

주) 김예린(2012)의 연구를 토대로 일부 수정한 것임.

비스에 익숙해진 이용자들의 새로운 검색행태 를 수용할 수 있는 방향으로 발전해 나가는 것 이라 할 수 있다(윤정옥 2010). 이런 정의는 차 세대 도서관 목록과 혼용되어 사용되는 $\mathrm{OPAC}$ 2.0 에도 적용될 수 있을 것이다.

개념에 대한 공통된 의견이 없기 때문에 OPAC 2.0 기능에 대한 의견도 학자마다 다양 하다. OPAC 2.0의 기능에 대해 비교적 상세하 게 다룬 김예린(2012)의 연구에 의하면, 주요 선 행연구를 분석한 결과 제시된 기능 항목도 다양 하며, 동일한 기능에 대해서도 연구자마다 다른 용어를 사용한다고 언급하였다. 문헌에서 언급
된 $\mathrm{OPAC} 2.0$ 기능을 종합하면 〈표 1 〉과 같다.

\section{3. 공공도서관 $\mathrm{OPAC}$ 인터페이스 사례 분석}

연구대상 10 개 공공도서관 $\mathrm{OPAC}$ 인터페이 스를 분석원칙에 따라 분석한 결과는 다음과 같 다. 인터페이스의 '일관성'은 시스템이 일관적 으로 표현되고 작동하여, 이용자가 일관적인 결 과를 기대하도록 설계되어야 함을 뜻한다. 이 연구에서는 $\mathrm{OPAC}$ 검색과정에서 사용하는 용 
어의 일관성을 조사하였다. 국내 공공도서관 중 SLIMA와 DLS의 경우 각 검색창에서 제공하는 검색 항목의 용어가 상이하였고, 나머지 OPAC 은 검색과정에서 나타난 용어 및 검색 순서가 일관성이 있었다. 국외 대부분의 $\mathrm{OPAC}$ 은 홈페 이지 첫 화면에 간단 검색창을 제시하고 주 메 뉴를 통해 검색메뉴를 제공하거나 확장검색 링 크를 제공하며, 동일 용어를 사용하여 일관성이 있는 것으로 조사되었다.

이용자가 실수할 수 있다는 점이 시스템에서 고려되어야 함을 뜻하는 '관용성'의 분석결과는 〈표 2〉와 같다. 국내 $\mathrm{OPAC}$ 중 검색어 자동완 성 기능은 DJHLS와 GODIS-NET가, 철자 오 류검증 기능은 DJHLS가, 국외 OPAC 중 검색 어자동완성 기능은 Polaris ILS와 Koha, LS $2 \mathrm{PAc}$ 이, 태그 클라우드 기능은 Koha에서 제공 하여, 이용자의 검색 실수를 예방한다.

인터페이스 설계에 있어 '직관성'은 시스템에 서 이용자가 원하는 기능이 한눈에 드러나도록 설계되어야 함을 원칙으로 하는 것으로 국내 공 공도서관 $\mathrm{OPAC}$ 인터페이스에서는 여러 단계 를 걸치지 않아도 이용자가 직관적으로 검색을 할 수 있도록 환경이 조성되어 있다. 국외의 공 공도서관도 간단 검색창을 도서관 홈페이지 창 의 상단 오른쪽 혹은 정중앙에 위치함으로써 이
용자의 시선을 끌고 있어 이용자가 쉽게 정보를 검색할 수 있다. 인터페이스의 직관성을 높여주 는 기능으로 위젯을 예로 들 수 있다. SLIMA는 도서예약 및 전자도서관 이용, 대출 정보 확인에 대한 위젯을 제공하고 그 외 KOLASIII, DLS, DJHLS, GOLDIS-NET은 제공하지 않는다. 국 외의 경우 위젯을 모두 제공하지 않는다.

'적합성'은 이용자가 시스템의 상태를 알 수 있도록 설계되거나, 이용자가 의도한 대로 시스 템을 제어할 수 있고, 개인화가 가능하도록 설 계되어야 함을 말한다. $\mathrm{OPAC}$ 인터페이스의 '적 합성'은 정렬 기능을 중심으로 분석하였고 그 결과는 〈표 3〉과 같다. KOLASIII 와 DLS는 표 제, 저자, 발행년, 발행자로 정렬이 가능하였고, SLIMA는 표제, 저자, 발행년, 발행자 외에 청 구기호순의 정렬이 가능하였다. DJHLS는 표제 와 발행년, 청구기호순, 정확도, 인기도 정렬 기 능을 제공하였고, GOLDIS-NET은 정렬기능 을 제공하고 있지 않았다. 국외 $\mathrm{OPAC}$ 의 경우 Polaris ILS는 가장 많은 정렬 기능을 제공하고 있는데, 기본적으로 서명, 저자, 발행년, 청구기호 를 제공하고 각 항목의 조합에 대한 정렬기능을 제공하였다. Symphony와 Polaris ILS, Koha 는 적합성에 대한 정렬기능을 제공하고 있으며, Polaris ILS와 Koha는 자료의 인기에 따른 정

〈표 2〉 국내 · 외 공공도서관 OPAC 인터페이스 관용성 기능 제공 유무 비교

\begin{tabular}{l|c|c|c|c|c|c|c|c|c|c}
\hline \hline & $\begin{array}{c}\text { KOLAS } \\
\text { III }\end{array}$ & DLS & SLIMA & DJHLS & $\begin{array}{c}\text { GOLDIS } \\
\text {-NET }\end{array}$ & $\begin{array}{c}\text { Symp- } \\
\text { hony }\end{array}$ & Apollo & $\begin{array}{c}\text { Polaris } \\
\text { ILS }\end{array}$ & Koha & $\begin{array}{c}\text { LS2 } \\
\text { PAC }\end{array}$ \\
\hline 검색어자동완성 & $\times$ & $\times$ & $\times$ & $\circ$ & $\circ$ & $\times$ & $\times$ & $\circ$ & 0 & 0 \\
\hline 철자오류검증 & $\times$ & $\times$ & $\times$ & $\circ$ & $\times$ & $\times$ & $\times$ & $\times$ & $\times$ & $\times$ \\
\hline 태그 클라우드 & $\times$ & $\times$ & $\times$ & $\times$ & $\times$ & $\times$ & $\times$ & $\times$ & $\circ$ & $\times$ \\
\hline 관련자료추천 & $\times$ & $\times$ & $\times$ & $\times$ & $\times$ & $\times$ & $\times$ & $\times$ & $\times$ & $\times$ \\
\hline
\end{tabular}


〈표 3〉국내 - 외 공공도서관 OPAC 인터페이스 정렬기능 비교

\begin{tabular}{|c|c|c|c|c|c|c|c|c|c|c|}
\hline & $\begin{array}{c}\text { KOLAS } \\
\text { III }\end{array}$ & DLS & SLIMA & DJHLS & $\begin{array}{l}\text { GOLDIS } \\
\text {-NET }\end{array}$ & $\begin{array}{l}\text { Symp- } \\
\text { hony }\end{array}$ & Apollo & $\begin{array}{l}\text { Polaris } \\
\text { ILS }\end{array}$ & Koha & $\begin{array}{l}\text { LS2 } \\
\text { PAC }\end{array}$ \\
\hline 적합성 & $x$ & $x$ & $x$ & $x$ & $\times$ & 0 & $x$ & 0 & 0 & $x$ \\
\hline 표제 오름, 내림차순 & 0 & 0 & 0 & 0 & $x$ & 0 & $x$ & 0 & 0 & 0 \\
\hline 저자 오름, 내림차순 & 0 & O & O & $x$ & $x$ & 0 & $x$ & O & O & O \\
\hline 발행년오름, 내림차순 & 0 & 0 & 0 & 0 & $x$ & $x$ & $x$ & 0 & 0 & 0 \\
\hline 발행자 오름, 내림차순 & 0 & 0 & 0 & $x$ & $x$ & $x$ & $x$ & $x$ & $x$ & $x$ \\
\hline 청구기호순 & $x$ & $x$ & O & 0 & $x$ & $x$ & $x$ & 0 & 0 & 0 \\
\hline 정확도순 & $x$ & $x$ & $x$ & O & $x$ & $x$ & $x$ & $x$ & $x$ & $x$ \\
\hline 인기순 & $x$ & $x$ & $x$ & O & $x$ & $x$ & $x$ & O & O & $x$ \\
\hline 주제 & $x$ & $x$ & $x$ & $x$ & $x$ & 0 & $x$ & $x$ & $x$ & $x$ \\
\hline 신간에서 구간 & $x$ & $x$ & $x$ & $x$ & $x$ & 0 & $x$ & $x$ & $x$ & $x$ \\
\hline 구간에서 신간 & $x$ & $x$ & $x$ & $x$ & $x$ & 0 & $x$ & $x$ & $x$ & $x$ \\
\hline 저자, 서명 & $x$ & $x$ & $x$ & $x$ & $x$ & $x$ & $x$ & 0 & $x$ & $x$ \\
\hline 저자, 발행년 & $x$ & $x$ & $x$ & $x$ & $x$ & $x$ & $x$ & 0 & $x$ & $x$ \\
\hline 서명, 저자 & $x$ & $x$ & $x$ & $x$ & $x$ & $x$ & $x$ & 0 & $x$ & $x$ \\
\hline 서명, 발행년 & $x$ & $x$ & $x$ & $x$ & $x$ & $x$ & $x$ & 0 & $x$ & $x$ \\
\hline 서명, 자료유형 & $x$ & $x$ & $x$ & $x$ & $x$ & $x$ & $x$ & O & $x$ & $x$ \\
\hline 발행년, 저자 & $x$ & $x$ & $x$ & $x$ & $x$ & $x$ & $x$ & 0 & $x$ & $x$ \\
\hline 발행년, 서명 & $x$ & $x$ & $x$ & $x$ & $x$ & $x$ & $x$ & 0 & $x$ & $x$ \\
\hline 청구기호, 저자 & $x$ & $x$ & $x$ & $x$ & $x$ & $x$ & $x$ & 0 & $x$ & $x$ \\
\hline 청구기호, 서명 & $x$ & $x$ & $x$ & $x$ & $x$ & $x$ & $x$ & 0 & $x$ & $x$ \\
\hline 청구기호, 발행년 & $x$ & $x$ & $x$ & $x$ & $x$ & $x$ & $x$ & 0 & $x$ & $x$ \\
\hline 등록번호 & $x$ & $x$ & $x$ & $x$ & $x$ & $x$ & $x$ & $x$ & $x$ & 0 \\
\hline
\end{tabular}

렬항목을 제공하고 있다. 그러나 Apollo의 경우 정렬항목을 제공하지 않고 있다.

인터페이스에서 개인화가 가능한 것은 정렬 이외에 추가 및 삭제 기능이다. 국내의 경우 간 략검색과 상세 검색을 선택적으로 사용할 수 있으나, 국외의 Polaris ILS, Koha는 이용자에 따라 검색항목을 추가 및 삭제하여 개인에 따 른 조건 설정이 가능하다.

'이용자 수준'은 인터페이스를 사용하는 이용 자의 시스템에 대한 숙련된 정도가 모두 다르므 로 숙련 수준을 고려하며, 이용자의 특성과 시 스템 이용 목적을 고려하여 설계되어야 함을 의
미한다. 국내 $\mathrm{OPAC}$ 은 어린이 또는 장애인 집 단, 특정 집단을 위한 별도의 인터페이스를 제 공하고 있지 않으며, 단일의 인터페이스를 운영 한다. 국외의 LS2PAC은 어린이 이용자를 위한 $\mathrm{OPAC}$ 인터페이스를 따로 제공하고 있다.

‘학습용이성'은 이용자가 시스템을 쉽게 익히 고 배울 수 있도록 설계되어야 함을 말한다. 국내 $\mathrm{OPAC}$ 의 경우 GOLDIS-NET와 DJHLS가 웹 포털과 유사한 검색창을 사용한다. 국외의 경우 Apollo를 제외한 네 개의 $\mathrm{OPAC}$ 이 웹 포털의 검 색창과 유사한 단순한 통합검색창을 제공하고 검 색 결과 디스플레이에서도 이용자가 어느 단계에 
서 시스템을 이용하고 있는지 식별이 가능하다.

'도움말'은 시스템이 제공하는 기능에 대한 도 움말을 제공해야 한다는 의미이다. 국내 $\mathrm{OPAC}$ 중 SLIMA와 GOLDIS-NET이 검색 도움말을 제공하고 있다. 국외 분석 대상 모든 $\mathrm{OPAC}$ 이 검색항목 및 검색어 조합 등에 대한 상세한 도 움말을 제공하고 있다.

인터페이스 설계원칙의 '가시성'은 화면 구 성이 정보나 기능이 명확하고 잘 구분이 될 수 있도록 설계되어야 함을 뜻하며, 이용자에게 알리고 싶은 정보가 있다면 이용자의 주의를 끌 수 있도록 설계되어야 함을 말한다. 분석결 과 〈표 4〉에서 보는 바와 같이, 국내 $\mathrm{OPAC}$ 중 KOLAS III 는 실시간 정보제공, DLS는 풍부한 콘텐츠와 실시간 정보제공, SLIMA는 풍부한 콘텐츠와 링킹사이트, 실시간정보제공, DJHLS 는 풍부한 콘텐츠와 이용자참여, 실시간정보제 공, GOLDIS-NET는 풍부한 콘텐츠 기능을 제 공하고 있다. 국외 OPAC 중 Symphony는 풍부 한 콘텐츠와 이용자참여, 실시간정보제공, Apollo 는 풍부한 콘텐츠와 실시간정보제공, Polaris ILS는 풍부한 콘텐츠와 링킹사이트 이용자참여, 소셜네트워크, 실시간정보제공, Koha는 풍부한
콘텐츠와 링킹사이트 이용자참여, 실시간정보제 공, LS2 PAC은 풍부한 콘텐츠와 이용자참여, 소 셜네트워크, 실시간정보제공 기능을 제공한다. '내비게이션'은 인터페이스에서 메뉴간의 이 동이 용이하고 이용자가 적합한 자료를 찾을 수 있도록 유도해야 함을 의미한다. OPAC 2.0 의 주요 기능인 패싯 내비게이션 기능 제공유무를 살펴보면, 국내 DLS는 키워드, 발행년도, 저자 등의 패싯을 제공하고 있다. 국외 Polaris ILS 와 Koha는 검색 결과를 제한하거나 확장하는 패싯을 장르, 주제, 저자, 시리즈, 인기도 등 다 양하게 제공한다.

인터페이스 설계원칙의 '시스템 피드백'은 이 용자가 시스템의 동작 상태나 작업 중인 내용을 즉각적으로 알 수 있는 상태를 말한다. 국내의 경우 검색 결과 값이 없을 경우 다른 검색어로 의 유도 및 검색어 철자 확인 등의 도움말을 통 한 재검색 유도는 SLIMA에서만 나타난다. 국 외는 이용자가 선택한 검색어를 항상 상위에 보 여주어 이용자가 작업 중인 내용에 대한 정보를 제공하며, 검색결과가 없는 경우 유사 키워드를 제시해주거나 다른 검색어를 사용하라는 메시 지를 제공하여 재검색을 유도한다.

〈표 4〉국내 - 외 공공도서관 OPAC 인터페이스 가시성 비교

\begin{tabular}{l|c|c|c|c|c|c|c|c|c|c}
\hline \hline & $\begin{array}{c}\text { KOLAS } \\
\text { III }\end{array}$ & DLS & SLIMA & DJHLS & $\begin{array}{c}\text { GOLDIS } \\
- \text { NET }\end{array}$ & $\begin{array}{c}\text { Symp- } \\
\text { hony }\end{array}$ & Apollo & $\begin{array}{c}\text { Polaris } \\
\text { ILS }\end{array}$ & Koha & $\begin{array}{c}\text { LS2 } \\
\text { PAC }\end{array}$ \\
\hline 풍부한 콘텐츠 & $\times$ & $\circ$ & $\circ$ & $\circ$ & $\circ$ & $\circ$ & $\circ$ & $\circ$ & $\circ$ & $\circ$ \\
\hline 링킹사이트 & $\times$ & $\times$ & $\circ$ & $\times$ & $\times$ & $\times$ & $\times$ & $\circ$ & $\circ$ & $\times$ \\
\hline 이용자참여 & $\times$ & $\times$ & $\times$ & $\circ$ & $\times$ & $\circ$ & $\times$ & $\circ$ & $\circ$ & $\circ$ \\
\hline 소셜네트워크 & $\times$ & $\times$ & $\times$ & $\times$ & $\times$ & $\times$ & $\times$ & $\circ$ & $\times$ & $\circ$ \\
\hline 시선추적 & $\times$ & $\times$ & $\times$ & $\times$ & $\times$ & $\times$ & $\times$ & $\times$ & $\times$ & $\times$ \\
\hline 매시업 & $\times$ & $\times$ & $\times$ & $\times$ & $\times$ & $\times$ & $\times$ & $\times$ & $\times$ & $\times$ \\
\hline 실시간정보제공 & $\circ$ & $\circ$ & $\circ$ & $\circ$ & $\times$ & $\circ$ & $\circ$ & $\circ$ & $\circ$ & $\circ$ \\
\hline
\end{tabular}


'실생활관행'은 실생활에서 사용하는 용어나 행동 양식을 차용하여 시스템의 기능이나 동작 방식을 이용자가 유추할 수 있도록 설계되어야 함을 의미한다. OPAC에서 '실생활관행'은 검색 항목에서 사용하는 용어를 분석하였고, 결과는 〈표 5〉와 같다. 국내 공공도서관 $\mathrm{OPAC}$ 인터페
이스는 검색에 있어 모두 디폴트 값으로 '전체' 혹은 '통합을 제시하고 있다. 국외 공공도서관의 검색에 있어 디폴트 값으로 Symphony와 LS2 PAC은 'keyword', Koha는 'library catalog', Apollo와 Polaris ILS는 각각 'all fields', 'any field’를 제시하고 있다.

〈표 5〉국내 - 외 공공도서관 OPAC 인터페이스 검색항목 언어 비교

\begin{tabular}{|c|c|c|c|c|c|c|c|c|c|c|}
\hline & $\begin{array}{c}\text { KOLA } \\
\text { SIII }\end{array}$ & DLS & SLIMA & DJHLS & $\begin{array}{c}\text { GOLDIS } \\
\text {-NET }\end{array}$ & $\begin{array}{c}\text { Symp- } \\
\text { hony }\end{array}$ & Apollo & $\begin{array}{c}\text { Polaris } \\
\text { ILS }\end{array}$ & Koha & $\begin{array}{l}\text { LS2 } \\
\text { PAC }\end{array}$ \\
\hline 디폴트 & 전체 & 전체 & 전체 & 통합 & 전체 & keyword & all fields & any field & $\begin{array}{l}\text { library } \\
\text { catalog }\end{array}$ & keyword \\
\hline 표제 & 표제 & 서명 & 서명 & - & 서명 & title & title & title & title & $\begin{array}{c}\text { title } \\
\text { browse }\end{array}$ \\
\hline 저자 & 저자 & 작가 & 저자명 & - & 저자 & author & author & author & author & $\begin{array}{c}\text { author or } \\
\text { name }\end{array}$ \\
\hline 발행자 & 발행자 & 발행자 & 출판사 & - & 출판사 & - & - & Publisher & - & - \\
\hline 키워드 & 키워드 & 키워드 & - & - & - & keyword & keyword & - & - & - \\
\hline 총서명 & - & - & 총서명 & - & - & series & - & series & series & series \\
\hline 주제 & - & - & 주제명 & - & & subject & - & subject & subject & subject \\
\hline 청구기호 & - & - & 청구기호 & - & - & - & $\begin{array}{c}\text { call } \\
\text { number }\end{array}$ & - & $\begin{array}{c}\text { Call } \\
\text { number }\end{array}$ & - \\
\hline 등록번호 & - & - & 등록번호 & - & - & - & - & - & - & - \\
\hline ISBN & - & - & $\begin{array}{l}\text { ISBN/ } \\
\text { ISSN }\end{array}$ & - & ISBN & - & - & ISBN & ISBN & $\begin{array}{l}\text { ISBN/ } \\
\text { ISSN }\end{array}$ \\
\hline 초록 & - & - & 초록 & - & - & - & - & - & - & - \\
\hline 분류기호 & - & - & - & - & 분류기호 & - & - & - & - & - \\
\hline 간행물서명 & - & - & - & - & - & $\begin{array}{c}\text { magazine } \\
\text { title }\end{array}$ & - & - & - & \\
\hline 매체유형 & - & - & - & - & - & - & $\begin{array}{c}\text { material } \\
\text { type }\end{array}$ & - & - & - \\
\hline 이용대상 & - & - & - & - & - & - & $\begin{array}{l}\text { accelerated } \\
\text { reader }\end{array}$ & - & - & - \\
\hline 일반주기 & - & - & - & - & - & - & - & $\begin{array}{c}\text { General } \\
\text { note }\end{array}$ & - & - \\
\hline 장르 & - & - & - & - & - & - & - & Genre & - & - \\
\hline ISSN & - & - & - & - & - & - & - & ISSN & - & ISSN \\
\hline $\mathrm{LCCN}$ & - & - & - & - & - & - & - & LCCN & - & - \\
\hline 발행자번호 & - & - & - & - & - & - & - & $\begin{array}{c}\text { Publisher } \\
\text { NO. }\end{array}$ & - & - \\
\hline STRN & - & - & - & - & - & - & - & STRN & - & - \\
\hline CODEN & - & - & - & - & - & - & - & CODEN & - & - \\
\hline SoDoc & - & - & - & - & - & - & & SoDoc & - & - \\
\hline
\end{tabular}




\section{4. 설문조사 분석}

\section{1 표본의 인구통계학적 특성}

설문에 참여한 표본은 총 174 명으로 이용자 와 사서의 집단, 성별, 연령으로 인구통계학적 특성을 살펴보면 〈표 6 〉과 같다. 참여한 표본 중 이용자가 $73 \%$ (127명)로 사서 $27 \%$ (47명) 보다 많았고, 성별에서는 여자가 $66.1 \%$ (115명)로 남
자 33.9\%(59명)보다 많았다. 그리고 표본의 연 령 분포는 30 대와 40 대가 각각 $24.1 \%$ (42명), 20 대 $20.7 \%$ (36명), 10대 $17.8 \%$ (31명), 50대 $13.3 \%$ (23명)으로 나타났다.

\section{2 도서관 OPAC 이용행태}

먼저 도서관 $\mathrm{OPAC}$ 이용 빈도는 〈표 7〉과 같다. 표본 중 $43.7 \%$ (76명)가 월 5 회 미만 이용

〈표 6〉 표본의 인구통계학적 분석

단위: 명 $(\%)$

\begin{tabular}{|c|c|c|c|}
\hline 문항 & 구분 & 응답수 & 총계 \\
\hline \multirow{2}{*}{ 이용자/사서 } & 이용자 & $127(73.0)$ & \multirow{2}{*}{$174(100)$} \\
\hline & 사서 & $47(27.0)$ & \\
\hline \multirow{2}{*}{ 성별 } & 남 & 59(33.9) & \multirow{2}{*}{$174(100)$} \\
\hline & 여 & $115(66.1)$ & \\
\hline \multirow{5}{*}{ 연령 } & 10대 & $31(17.8)$ & \multirow{5}{*}{$174(100)$} \\
\hline & 20대 & $36(20.7)$ & \\
\hline & 30대 & $42(24.1)$ & \\
\hline & 40대 & $42(24.1)$ & \\
\hline & 50대 & 23(13.3) & \\
\hline
\end{tabular}

〈표 7〉도서관 OPAC 인터페이스 이용 빈도

단위: 명 $(\%)$

\begin{tabular}{c|c|c|c|c|c|c|c}
\hline \hline \multirow{2}{*}{} & 구분 & 월5회 미만 & $\begin{array}{c}\text { 월5회 } \\
10 \text { 회 미만 }\end{array}$ & $\begin{array}{c}\text { 월10회 } \\
\text { 15회 미만 }\end{array}$ & $\begin{array}{c}\text { 월15회 } \\
\text { 20회 미만 }\end{array}$ & 기타 & 총계 \\
\hline \multicolumn{2}{c}{ 전체 표본 } & $76(43.7)$ & $43(24.7)$ & $19(10.9)$ & $25(14.4)$ & $11(6.3)$ & $174(100)$ \\
\hline \multirow{2}{*}{$\begin{array}{c}\text { 이용자/ } \\
\text { 사서 }\end{array}$} & 이용자 & $72(56.7)$ & $32(25.2)$ & $7(5.5)$ & $11(8.7)$ & $5(3.9)$ & $127(100)$ \\
\cline { 2 - 8 } & 사서 & $4(8.5)$ & $11(23.4)$ & $12(25.5)$ & $14(29.8)$ & $6(12.8)$ & $47(100)$ \\
\hline \multirow{3}{*}{ 성별 } & 남 & $27(45.8)$ & $13(22.0)$ & $4(6.8)$ & $11(18.6)$ & $4(6.8)$ & $59(100)$ \\
\cline { 2 - 8 } & 여 & $49(42.6)$ & $30(26.1)$ & $15(13.0)$ & $14(12.2)$ & $7(6.1)$ & $115(100)$ \\
\hline \multirow{5}{*}{ 연령 } & 10 대 & $22(71.0)$ & $4(12.9)$ & $0(0.0)$ & $1(3.2)$ & $4(12.9)$ & $31(100)$ \\
\cline { 2 - 8 } & 20 대 & $16(44.4)$ & $11(30.6)$ & $2(5.6)$ & $5(13.9)$ & $2(5.6)$ & $36(100)$ \\
\cline { 2 - 8 } & 30 대 & $13(31.0)$ & $12(28.6)$ & $6(14.3)$ & $8(19.0)$ & $3(7.1)$ & $42(100)$ \\
\cline { 2 - 8 } & 40 대 & $14(33.3)$ & $9(21.4)$ & $9(21.4)$ & $8(19.0)$ & $2(4.9)$ & $42(100)$ \\
\cline { 2 - 8 } & 50 대 & $11(47.8)$ & $7(30.4)$ & $2(8.8)$ & $3(13.0)$ & $0(0.0)$ & $23(100)$ \\
\hline
\end{tabular}


한다는 응답하였고, 다음으로는 월5 10회 미 만 이용이 24.7\%(43명), 월15 20회 미만 이용 이 $14.4 \%$ (25명), 월10 15회 미만 10.9\%(19 명) 순으로 나타났으며, 기타 응답은 6.3\%(11 명)로 나타났다. 기타 응답으로는 사서집단의 경우 수시로 혹은 월30회 이상을 사용한다는 응 답이 있었고, 이용자 집단은 사용하지 않다와 거의 사용하지 않는다의 응답이 있었다.

이용자 집단은 성별과 연령에 관련 없이 월5 회 미만의 이용이 가장 높은 응답으로 나타났 으며, 사서집단만이 월15회 20회 미만 29.8\% (14명), 월10회 15회 미만 25.5\%(12명), 월5 회 10회 미만 $23.4 \%$ (11명), 월5회 미만 8.5\% (4명) 순으로 나타났다.

다음으로 도서관 $\mathrm{OPAC}$ 의 이용 목적에 대 해 총 9 개의 선택사항을 제시하고 최대 3 가지 의 복수 응답을 받은 결과는 〈표 8>과 같다. 이 연구 표본의 이용목적은 찾고자 하는 자료의 소장 유무 $32.3 \%$ (169명), 대출 예약 및 대출자 료 반납연기 26.8\%(140명), 희망자료 신청 및 조회 $14.8 \%$ (77명), 신착자료 검색 $10.7 \%$ (56 명) 순으로 나타났다. 상호대차 서비스인 자료 배달 서비스에 대한 이용은 복수 응답임에도 불 구하고 매우 낮게 나타났으며, 복본 자료 조회 에 대한 응답은 사서 집단에서 볼 수 있는 특징 이었다.

도서관 $\mathrm{OPAC}$ 에서 자료 검색시 사용하는 항 목을 분석하기 위하여 총 8 개의 선택사항을 제 시하고 복수 응답을 받은 결과는 〈표 9 〉와 같다. 표본의 $32 \%$ (167명)가 도서관 OPAC 검색에 서 찾고자 하는 자료의 제목(서명)으로 검색을 하였고, 다음으로 저자(지은이) $28.1 \%$ (147명), 키워드 $11.8 \%(62$ 명 $)$ 순으로 나타났다.
〈표 8〉도서관 OPAC 이용 목적

\begin{tabular}{|c|c|}
\hline & $\begin{array}{c}\text { 단위: 명( } \\
\text { 응답수 }\end{array}$ \\
\hline 찾고자 하는 자료의 소장유무 & $169(32.3)$ \\
\hline 대출 예약 및 대출자료 연기 & $140(26.8)$ \\
\hline 희망자료 신청 및 조회 & $77(14.8)$ \\
\hline 신착자료 검색 & $56(10.7)$ \\
\hline 추천도서 확인 & $36(6.9)$ \\
\hline 도서대출베스트 조회 & $22(4.2)$ \\
\hline 복본자료 조회 & $17(3.3)$ \\
\hline 자료배달서비스 & $3(0.6)$ \\
\hline 기타 & $2(0.4)$ \\
\hline 계 & $522(100)$ \\
\hline
\end{tabular}

〈표 9〉도서관 OPAC 자료 검색 사용 항목 단위: 명 $(\%)$

\begin{tabular}{|c|c|}
\hline 이용 목적 & 응답수 \\
\hline 제목 & $167(32.0)$ \\
\hline 저자 & $147(28.1)$ \\
\hline 키워드 & $62(11.8)$ \\
\hline 출판사 & $55(11.0)$ \\
\hline 주제명 & $42(8.0)$ \\
\hline 전체 & $33(6.2)$ \\
\hline 분류기호 & $13(2.4)$ \\
\hline ISBN & $3(0.5)$ \\
\hline 계 & $522(100)$ \\
\hline
\end{tabular}

\section{3 도서관 $\mathrm{OPAC}$ 인터페이스 만족도}

공공도서관 $\mathrm{OPAC}$ 인터페이스의 만족도 및 난이도를 분석하기 위하여 화면구성의 만족도, 검색 결과 정보의 만족도, 검색 수행의 난이도, 키워드 제공의 만족도, 주제어 제공의 만족도, 목차, 초록, 이용대상과 같은 정보 제공의 만족 도 총 6 개 문항으로 구성하였다. 각 문항은 리커 트 5점 척도를 사용하였다.

전체 표본에 대한 분석 결과는 〈표 10〉에서 
〈표 10〉전체 표본의 도서관 OPAC 인터페이스의 만족도 및 난이도

\begin{tabular}{l|c|c}
\hline \multicolumn{1}{c|}{ 문항 } & 평균값 & 표준편차 \\
\hline 자료검색 화면구성의 만족도 & 3.58 & 0.834 \\
\hline 자료 검색 결과 정보의 만족도 & 3.61 & 0.803 \\
\hline 자료 검색의 난이도 & 3.67 & 0.834 \\
\hline 자료 검색을 위한 충분한 키워드 제공의 만족도 & 3.11 & 0.870 \\
\hline 자료 검색을 확장할 수 있는 주제어 제공의 만족도 & 2.98 & 0.915 \\
\hline 목차, 초록, 이용대상과 같은 정보 제공의 만족도 & 2.84 & 0.936 \\
\hline
\end{tabular}

〈표 11〉이용자 집단에 따른 도서관 OPAC 인터페이스의 만족도 및 난이도

\begin{tabular}{l|c|c|c|c|c|c|c|c|c}
\multirow{2}{*}{ 문항 } & \multicolumn{2}{|c|}{ 이용자/사서 } & \multicolumn{2}{|c|}{ 성별 } & \multicolumn{5}{c}{ 연령 } \\
\cline { 2 - 12 } & 이용자 & 사서 & 남 & 여 & 10 대 & 20 대 & 30 대 & 40 대 & 50 대 \\
\hline 자료검색 화면구성의 만족도 & 3.6 & 3.53 & 3.61 & 3.57 & 3.74 & 3.53 & 3.57 & 3.48 & 3.48 \\
\hline 자료 검색 결과 정보의 만족도 & 3.61 & 3.62 & 3.56 & 3.63 & 4.0 & 3.42 & 3.57 & 3.52 & 3.52 \\
\hline 자료 검색의 난이도 & 3.66 & 3.7 & 3.64 & 3.69 & 3.87 & 3.78 & 3.67 & 3.45 & 3.45 \\
\hline 자료 검색을 위한 충분한 키워드 제공의 만족도 & 3.12 & 3.09 & 3.05 & 3.14 & 3.65 & 3.22 & 3.12 & 2.79 & 2.79 \\
\hline 자료 검색을 확장할 수 있는 주제어 제공의 만족도 & 3.06 & 2.79 & 2.97 & 2.99 & 3.61 & 3.14 & 2.81 & 2.69 & 2.69 \\
\hline 목차, 초록, 이용대상과 같은 정보 제공의 만족도 & 2.95 & 2.53 & 2.69 & 2.91 & 3.48 & 2.97 & 2.67 & 2.52 & 2.52 \\
\hline
\end{tabular}

와 같이 자료 검색 난이도가 3.67 로 가장 높았 고, 자료 검색 결과 정보의 만족도 3.61 , 자료검 색 화면구성의 만족도 3.58 , 자료 검색을 위한 충분한 키워드 제공 3.11 , 자료 검색을 확장할 수 있는 주제어 제공 2.98 , 목차, 초록, 이용대상 과 같은 정보 제공에 대한 만족도가 2.84로 나 타났다.

이용자 집단에 따른 도서관 $\mathrm{OPAC}$ 인터페 이스의 만족도 및 난이도는 〈표 11〉에서처럼 전체 표본의 만족도 경향과 거의 유사하다. 모든 집단이 목차, 초록 등의 정보제공에 대 한 만족도가 제일 낮았으며, 이용자 집단과 사 서집단을 비교하였을 때 주제어 제공 및 목차 등 정보 제공의 만족도가 낮았다. 또한 연령 에 따라서 10 대, 20 대, 30 대의 경우는 화면구
성, 만족도, 난이도, 키워드 문항에서 보통 이상 의 만족도로 분석된 반면, 40 대와 50 대는 충분 한 키워드 제공에서 2.79 의 낮은 만족도로 나타 났다.

\section{4 도서관 $\mathrm{OPAC} 2.0$ 기능 요구도}

이 절에서는 공공도서관의 $\mathrm{OPAC} 2.0$ 의 기 능에 대한 요구도를 분석하였다. OPAC 2.0 기 능에 대한 전체 표본의 요구도를 산출하고 기 능의 요구도 순위를 조사하였다. 또한 표본의 인구통계학적인 특성인 이용자/사서 집단비교, 성별비교, 연령에 따른 OPAC 2.0 의 기능 요구 도 차이를 비교하였다. 
4.4.1 전체 표본의 $\mathrm{OPAC} 2.0$ 기능 요구도 공공도서관 $\mathrm{OPAC} 2.0$ 기능에 대한 전체 표 본의 요구도 분석결과는 〈표 12〉와 같다.

설문 분석 결과, 표본은 $\mathrm{OPAC} 2.0$ 의 기능 중 소장 정보와 대출상황에 대한 실시간 정보 제공 에 대한 기능 요구도가 4.30 으로 가장 높았으며, 두 번째로는 서평, 저자소개 등 풍부한 콘텐츠 제공에 대한 요구도로 3.91 로 나타났다. 다음으 로 검색어의 철자오류 수정은 3.87 , 검색 결과 중 같은 자료를 선택한 이용자가 본 다른 자료 를 추천해주는 관련 자료 추천은 3.84 , 검색어 자동 완성 기능에 대한 요구도는 3.82 순으로 나 타났다.

가장 낮은 요구도로는 $\mathrm{OPAC}$ 의 검색 결과를 트위터, 블로그, 페이스북 등에 연결하는 소셜 네트워크 기능으로 3.24 로 나타났다. 그러나 이 번 설문 결과 OPAC 2.0 기능은 평균값 이상의 요구도를 보이는 것으로 분석되었다.
4.4.2 집단에 따른 OPAC 2.0 기능 요구도

1) 이용자/사서 집단 기능 요구도

이용자와 사서 집단 사이에서의 도서관 $\mathrm{OPAC}$ 2.0 기능에 대한 요구도 차이는 유의수준 0.05 내에서 〈표 13〉에서와 같이 풍부한 콘텐츠, 링 킹사이트, 실시간 정보제공, 매쉬업 기능이 의 미가 있는 것으로 나타났다. 그 밖에 OPAC 기 능에 대한 요구도는 통계적으로 유의한 차이가 나타나지 않았다.

그러나 OPAC 기능에 대한 이용자 및 사서 집단의 요구도 순위는 두 집단 모두 소장자료에 대한 실시간 정보제공이 가장 높았으며, 소셜네 트워크, 이용자 참여에 대한 기능 요구도가 가 장 낮게 나타났다.

2) 연령과 성별에 따른 기능 요구도

연령에 따른 도서관 $\mathrm{OPAC}$ 인터페이스 기능 요구도의 차이는 풍부한 콘텐츠를 제외한 기능 에서 유의수준 0.05 내에서 차이가 없는 것으로

〈표 12〉전체 표본의 OPAC 2.0 기능 요구도

\begin{tabular}{l|c|c|c}
\hline \multicolumn{1}{c|}{ 문항 } & 평균값 & 표준편차 & 순위 \\
\hline 소장정보와 대출상황 실시간 정보제공 & 4.30 & 0.834 & 1 \\
\hline 서평, 저자소개 등 풍부한 콘텐츠 & 3.91 & 0.789 & 2 \\
\hline 검색어의 철자오류 수정 기능 & 3.87 & 0.851 & 3 \\
\hline 관련자료추천 & 3.84 & 0.72 & 4 \\
\hline 검색어 자동완성 & 3.82 & 0.854 & 5 \\
\hline 패싯내비게이션 & 3.64 & 0.840 & 6 \\
\hline 이용자참여 & 3.48 & 0.838 & 7 \\
\hline 위젯 & 3.48 & 0.885 & 7 \\
\hline 시선추적페이지구성 & 3.44 & 0.903 & 9 \\
\hline 태그클라우드 & 3.41 & 0.761 & 10 \\
\hline 링킹사이트 & 3.41 & 0.874 & 10 \\
\hline 매쉬업 & 3.39 & 0.851 & 12 \\
\hline 소셜네트워크 & 3.24 & 0.918 & 13 \\
\hline
\end{tabular}


〈표 13〉이용자/사서 집단의 OPAC 2.0 기능 요구도 차이

\begin{tabular}{l|c|c|c|c}
\multirow{2}{*}{ 문항 } & \multicolumn{2}{|c|}{ 평균 } & \multirow{2}{*}{ 유의확률 } \\
\cline { 2 - 4 } & 이용자 & 사서 & & .016 \\
\hline 서평, 저자소개 등 풍부한 콘텐츠 & 3.83 & 4.15 & -2.425 & .024 \\
\hline 링킹 사이트 & 3.32 & 3.66 & -2.283 & .008 \\
\hline 소장정보와 대출상황 실시간 정보제공 & 4.20 & 4.57 & -2.698 & .028 \\
\hline 매쉬업 & 3.30 & 3.62 & -2.213 & \\
\hline
\end{tabular}

나타났다. 풍부한 콘텐츠에 관련한 기능은 연령 이 낮을수록 요구도가 높게 나타나는 것으로 분 석되었다.

연령에 따른 $\mathrm{OPAC}$ 인터페이스 기능에 대한 요구도는 평균적으로 40 대가 가장 높았고, 30 대, 20대, 10대 순으로 나타났으며, 50대는 전체 적으로 $\mathrm{OPAC}$ 인터페이스 기능에 대한 요구도 가 낮은 것으로 분석되었다. 또한 연령에 따른 $\mathrm{OPAC}$ 기능에 대한 요구도 순위는 다른 집단 및 일반적인 인구 표본의 순위와 같은 경향성을 띄었다. 반면 성별에 따른 집단의 차이는 유의 미한 차이가 나타나지 않았다.

\section{5 도서관 $\mathrm{OPAC}$ 인터페이스 개선 요구도}

\subsection{1 전체 표본의 개선 요구도}

$\mathrm{OPAC}$ 인터페이스 개선에 대한 표본의 요구 도 분석은 〈표 14〉와 같다. 도서관 $\mathrm{OPAC}$ 인터
페이스를 구성하는 용어가 실생활에서 사용하 는 용어로 이루어져야 한다는 요구가 가장 높게 나타났으며, 이용자 수준에 맞는 검색방법 제시, 검색방법에 대한 자세한 도움말, 이용자 스스로 인터페이스를 통해서 학습할 수 있는 학습용이 성 순으로 분석되었고 이용자가 개인 맞춤화할 수 있는 $\mathrm{OPAC}$ 인터페이스의 이용자 편집 기능 은 가장 낮게 요구되는 것으로 분석되었다.

\subsection{2 이용자/사서 집단 개선 요구도}

〈표 15〉에서와 같이 이용자 및 사서 집단의 $\mathrm{OPAC}$ 인터페이스 개선 요구도는 유의확률 0.05 내에서 이용자 수준에 따르는 검색방법 제공, 학 습 용이성 항목에 대하여 유의미한 것으로 분석 되었다.

\subsection{3 연령에 따른 개선 요구도}

연령에 따른 도서관 $\mathrm{OPAC}$ 인터페이스 개선

〈표 14〉전체 표본의 도서관 OPAC 인터페이스 개선 요구도

\begin{tabular}{l|c|c|c}
\hline \multicolumn{1}{c|}{ 문항 } & 평균값 & 표준편차 & 순위 \\
\hline 검색 메뉴 용어의 생활어휘 사용 & 3.83 & .836 & 1 \\
\hline 이용자수준 따른 검색 방법 제공 & 3.80 & .802 & 2 \\
\hline 자료검색에 대한 자세한 도움말 & 3.75 & .762 & 3 \\
\hline 검색 방법에 대한 학습 용이성 & 3.72 & .807 & 4 \\
\hline 자료검색 화면의 이용자 편집 기능 & 3.37 & .927 & 5 \\
\hline
\end{tabular}


〈표 15〉이용자/사서 집단의 개선 요구도 차이

\begin{tabular}{l|c|c|c|c}
\hline \multirow{2}{*}{ 문항 } & \multicolumn{2}{|c|}{ 평균 } & \multirow{2}{*}{$\mathrm{t}$} & \multirow{2}{*}{ 유의확률 } \\
\cline { 2 - 4 } & 이용자 & 사서 & & \\
\hline 이용자수준 따른 검색 방법 제공 & 3.71 & 4.06 & -2.637 & .009 \\
\hline 검색 방법에 대한 학습 용이성 & 3.64 & 3.96 & -2.349 & .020 \\
\hline
\end{tabular}

요구도 차이의 분석 결과, 학습용이성에 대한 개선 요구도가 유의수준 0.05 내에서 유의미 한 차이가 있는 것으로 나타났으며, 인터페이 스의 자세한 도움말과 이용자 편집 가능성은 집단 간의 유의미한 차이가 없는 것으로 나타 났다.

연령에 따른 OPAC 인터페이스 개선 요구 도는 평균적으로 40대가 가장 높았고, 그 다음 으로 50 대가 개선에 대한 요구도가 높았으며, 30 대, 20 대, 10 대 순으로 요구도를 보였다. 검 색 방법에 대한 학습 용이성은 50 대가 가장 높 게 요구하고 있으며, 나머지 문항 즉, 이용자 수 준, 도움말, 편집기능, 생활어휘 사용에 관해서 는 40 대가 가장 높게 요구하는 것으로 분석되 었다.

\subsection{4 도서관 $\mathrm{OPAC}$ 인터페이스 개선 필수 사항}

$\mathrm{OPAC}$ 인터페이스가 개선되기 위한 필수사 항에 대한 분석 결과는 〈표 16〉과 같다. 표본의 $51.7 \%$ (90명)는 데이터베이스에 자료의 정보와 관련된 사항을 완전히 입력하는 것이 인터페이 스 개선에 있어 필수사항이라고 응답했다. 즉 표본의 응답 결과는 서지데이터의 완전한 입력 이 도서관 $\mathrm{OPAC}$ 인터페이스 개선에 있어서 전 제 조건이라고 분석할 수 있다.

그 밖에 외부 정보 자원의 링크를 통해서 개 선될 수 있다는 응답은 $15.5 \%$ (27명)로, 다양한 형태의 전자 정보를 도서관 홈페이지를 통해서 제공을 원한다는 응답인 $22.4 \%$ (39명) 보다 낮 게 나타났다. 사서집단의 경우를 제외하고 성

〈표 16〉도서관 OPAC 인터페이스 개선 필수사항

단위: 명 $(\%)$

\begin{tabular}{c|c|c|c|c|c|c|c}
\hline \hline & 구분 & 완전한입력 & 외부자원링크 & 외형적변화 & 전자정보제공 & 기타 & 총계 \\
\hline \multicolumn{2}{c|}{ 전체 표본 } & $90(51.7)$ & $27(15.5)$ & $17(9.8)$ & $39(22.4)$ & $1(0.6)$ & $174(100)$ \\
\hline \multirow{2}{*}{$\begin{array}{c}\text { 이용자/ } \\
\text { 사서 }\end{array}$} & 이용자 & $61(48.0)$ & $15(11.8)$ & $14(11)$ & $36(28.3)$ & $1(0.9)$ & $127(100)$ \\
\cline { 2 - 8 } & 사서 & $29(61.7)$ & $12(25.5)$ & $3(6.4)$ & $3(6.4)$ & $0(0.0)$ & $47(100)$ \\
\hline \multirow{4}{*}{ 성별 } & 남 & $31(52.5)$ & $11(18.6)$ & $4(6.8)$ & $12(20.3)$ & $1(1.8)$ & $59(100)$ \\
\cline { 2 - 8 } & 여 & $59(51.3)$ & $16(13.9)$ & $13(11.3)$ & $27(23.5)$ & $0(0.0)$ & $115(100)$ \\
\hline \multirow{5}{*}{ 연령 } & 10 대 & $14(45.1)$ & $2(6.5)$ & $4(12.9)$ & $10(32.3)$ & $1(3.2)$ & $31(100)$ \\
\cline { 2 - 8 } & 20 대 & $18(50)$ & $5(13.9)$ & $4(11.1)$ & $9(25)$ & $0(0.0)$ & $36(100)$ \\
\cline { 2 - 8 } & 30 대 & $26(61.9)$ & $6(14.3)$ & $5(11.9)$ & $5(11.9)$ & $0(0.0)$ & $42(100)$ \\
\cline { 2 - 8 } & 40 대 & $21(50)$ & $10(23.8)$ & $2(4.8)$ & $9(21.4)$ & $0(0.0)$ & $42(100)$ \\
\cline { 2 - 8 } & 50 대 & $11(47.8)$ & $4(17.4)$ & $2(8.7)$ & $6(26.1)$ & $0(0.0)$ & $23(100)$ \\
\hline
\end{tabular}


별, 연령별 집단 및 이용자 집단은 표본의 전체 통계와 같은 경향을 보이고 있으며, 사서집단 의 경우는 데이터의 완전한 입력, 외부자원 링 크, 도서관 홈페이지의 외형적 변화 순으로 분 석되었다.

기타 의견으로 도서관 $\mathrm{OPAC}$ 인터페이스에 대하여 개방형 질문에 대한 응답으로 표본은 이 해하기 쉽고 간단한 검색 시스템을 원한다고 응 답하였으며, 그 밖에도 소장 자료 검색 결과에 대한 자료 위치 안내, 검색 결과에 대한 풍부한 정보 제공과 그러한 정보를 개인의 기호에 따라 선택적으로 사용 가능하도록 인터페이스가 구 성되길 원한다고 응답하였다.

\section{5. 결론 및 제언}

이 연구에서는 공공도서관 $\mathrm{OPAC}$ 인터페이 스 발전방안을 제시하기 위하여, 국내 - 외 공공 도서관 $\mathrm{OPAC}$ 인터페이스를 인터페이스 설계 원칙에 따라 조사하고, 공공도서관 $\mathrm{OPAC}$ 인터 페이스에 관련한 이용자 요구를 설문조사하였 다. 연구결과 공공도서관 $\mathrm{OPAC}$ 인터페이스의 발전방안을 제시하면 다음과 같다.

첫째, "일관성' 측면에서 공공도서관의 OPAC 인터페이스는 자료의 검색과 검색결과 리스트, 결과 자료의 확인 과정까지 용어나 검색 순서의 일관성을 제공하고 자료 검색의 다양한 방법 즉 통합검색, 간략검색, 고급검색 등의 기능이 일 관적 및 단계적으로 사용될 수 있도록 제시하여 야 한다. 국외 도서관의 $\mathrm{OPAC}$ 에서 사용되는 어휘는 통일되어 제공하고 있으나, 국내 도서관 의 일부 $\mathrm{OPAC}$ 에서는 검색과정마다 상이한 용
어가 사용되고 있었다.

둘째, '관용성'의 측면에서 $\mathrm{OPAC}$ 의 기능 중 검색어 철자 오류 검증과 검색어 자동완성 기능 제공을 통해 인터페이스의 관용성을 높일 수 있 다. 이용자는 철자오류 검증에 대한 기능을 높 게 요구했으며 이 외에도 관련자료 추천을 통해 이용자가 적합한 자료를 찾기 위한 정보를 최대 한 제시해 줘야 한다. 이 연구에서 분석한 일부 국내 - 외 $\mathrm{OPAC}$ 이 철자오류수정과 검색어 자 동완성 등에 대한 기능을 제공하였고, 이용자 요구 분석을 통해서 밝혀진 것과 같이 OPAC 인터페이스 구성에 있어 다양한 관용성 장치를 마련해야 한다.

셋째, '직관성'의 측면에서 $\mathrm{OPAC}$ 의 위젯 기 능이 인터페이스의 직관성을 높일 수 있으나, 이용자 요구도는 높게 나타나지 않았다. 통합 검색창은 도서관 메인 홈페이지에 오른쪽 상단 또는 중앙에 배치되어 있어야 하며, 도서관 메 인 메뉴에서도 찾아 들어갈 수 있도록 메뉴에 서도 명확한 언어로 표현되어야 한다. 확장검 색까지 연결될 수 있도록 직관성 높은 설계가 필요하다.

넷째, '적합성'의 측면에서 $\mathrm{OPAC}$ 인터페이 스는 검색된 방대한 자료 중에서 이용자가 적합 한 자료를 찾아내고 분류할 수 있도록 설계되어 야 한다. 국외 공공도서관의 다양한 정렬 기준 중에서 특히 적합성 및 인기도는 인터페이스의 적합성을 높이는 효과적인 방법이다. 사례 분석 한 국외 Polaris ILS에서 제공하고 있는 적합성 과 인기도 및 기타 여러 가지의 정렬 조건은 좋 은 예를 보여 주고 있으며, 특히 디폴트가 적합 성으로 되어 있어 검색 결과에 대한 신뢰를 높 일 수 있다. 국내 공공도서관에서도 최근 개발 
된 $\mathrm{OPAC}$ 인터페이스에서 찾아 볼 수 있으며, 향후 적합성에 대한 정렬 기능 확대는 $\mathrm{OPAC}$ 인터페이스의 이용자 만족에 대한 중요한 척도 가 될 것이다.

다섯째, '이용자 수준'의 측면에서 다양한 이 용자가 이용하는 공공도서관은 특히 이용자의 다양성과 더불어 $\mathrm{OPAC}$ 인터페이스에도 이용 자 수준이 고려되어야 한다. 설문조사 분석에서 도 $\mathrm{OPAC}$ 인터페이스 개선 요구도 중 이용수준 에 따른 검색 방법 제공이 가장 높게 나타났다. 국내 공공도서관은 어린이, 노인, 다문화 등 다 양한 계층을 위한 인터페이스를 제공하지 않는 다. 언어서비스 및 대활자 크기 등은 일부 항목 에서만 보여 질 뿐 실제적 자료를 검색하고 결 과를 확인하는 서비스에서는 이용자 수준은 고 려되고 있지 않다. 공공도서관 $\mathrm{OPAC}$ 인터페이 스는 이용자 수준에 따라 선택적으로 사용할 수 있는 인터페이스 설계가 시급하다. 국외 도서관 $\mathrm{OPAC}$ 인터페이스 중 LS2PAC은 어린이를 위 한 $\mathrm{OPAC}$ 인터페이스를 따로 제공하고 있으며, 캐릭터와 애니메이션 구성으로 제공하여 쉽게 자료 검색을 할 수 있도록 제공하고 있다. 어린 이를 위한 $\mathrm{OPAC}$ 인터페이스 제공은 어린이 스 스로 검색 방법을 습득하는 것을 돕고, $\mathrm{OPAC}$ 이용방법을 습득할 수 있도록 도와줄 것이다.

여섯째, '학습용이성'의 측면에서 설문조사에 서 이용자 집단 중 50 대에서 가장 높은 요구도 로 분석되었다. 또한 웹 포털 검색에 익숙한 이 용자 집단을 위하여 어디에서도 통용될 수 있는 검색 방법 및 검색 결과를 확인하는 일련의 과 정이 이루어질 수 있도록 설계되어야 할 것이다. 이용자는 인터넷 이용 습관으로 충분히 OPAC 을 쉽게 이용할 수 있도록, 웹 포털 형식의 통합
검색 도입과 이용자가 검색 창 편집이 가능한 확장 검색 등도 고려한 $\mathrm{OPAC}$ 인터페이스가 구 축되어야 한다.

일곱째, '도움말'의 측면에서 이용자는 검색 방법 및 $\mathrm{OPAC}$ 시스템에 대한 안내 및 도움말 을 선택하여 볼 수 있어야 하며, 인터페이스는 상세한 도움말을 제공해야 한다. 국외 $\mathrm{OPAC}$ 은 모두 도움말을 제공하고 있으나, 국내 $\mathrm{OPAC}$ 은 일부에서만이 도움말을 제공하고 있었다. 또한 도움말을 구성할 때에도 생활용어로 설명함으 로서 이용자가 쉽게 이해할 수 있도록 설계되어 야 한다.

여덟째, '가시성'의 측면에서 OPAC 인터페 이스는 시각적 디자인이 즐거움을 줄 수 있어야 하며 기능이나 정보가 명확하고 잘 구분되도록 설계되어야 한다. 특히 이용자 설문조사에서 기 능 요구도가 높게 나타난 풍부한 콘텐츠로 이용 자에게 명확한 정보를 다양하게 제시하여야 할 것이다. 또한 소장 자료에 대한 실시간 정보 제 공은 이용자의 요구도가 가장 높게 나타난 항목 으로서 이용자가 확인이 용이하도록 설계되어 야 한다. 그러나 소셜 네트워크 및 이용자 참여, 매쉬업, 링킹사이트 기능은 이용자의 요구도가 다른 기능과 비교하여 낮기 때문에 기능 도입에 있어 자관의 이용자 이용행태를 파악하여 제공 유무를 판단한 후 설계해야 할 것이다.

아홉째, '내비게이션'의 측면에서 OPAC 인 터페이스에 있어 패싯 내비게이션은 이용자의 검색을 확장하거나 검색을 좁혀나갈 수 있도록 탐색의 방향을 제시하기 때문에 매우 유용하다. 사례분석 결과 내비게이션 기능은 몇몇 $\mathrm{OPAC}$ 에서만 사용하였고, 이용자 요구도 3.64 로 높게 나타나지 않았다. 그러나 자료의 유형, 저자, 이 
용대상, 인기도와 같은 패싯은 이용자의 검색활 동을 돕는 중요한 도구로서 인터페이스 설계에 고려되어야 한다.

열 번째, '시스템 피드백' 측면에서 검색 결과 가 없을 때에 이용자의 검색어에 대한 점검을 유도하고 유사 검색어 제시를 통해 재탐색이 이 루어 질 수 있도록 OPAC 시스템은 지속적인 피드백을 이용자에게 제시하여야 한다. 또한 이 용자는 현재 $\mathrm{OPAC}$ 시스템 중 어느 부분에 있 는지, 자료 검색에 있는지, 자료 검색 결과 확인 에 있는지, 처음 상태로 돌아갈 수 있는 방법에 대해서 안내가 있어야 하며, 이용자가 수행하고 있는 작업에 대하여 제시해 줄 수 있는 시스템 피드백이 제공되어야 한다.

열한 번째, '실생활 관행'의 측면에서 인터페 이스에서 사용되는 언어 및 용어는 이용자가 일 상적으로 쓰는 언어로 표현되어야 하며 행동 양 식에서도 이용자가 주로 검색하는 항목을 상위 에 배치함으로써 더 적합한 검색 결과 값을 얻 을 수 있도록 인터페이스는 설계되어야 할 것 이다. 설문조사에 따르면, 이용자의 인터페이스 개선 요구에 있어서 생활어휘 사용이 가장 높 게 분석된 것으로 나타났으며, 이는 공공도서관 $\mathrm{OPAC}$ 인터페이스의 용어가 생활용어와 비교
하여 차이가 있을 경우 변경해야 할 필요성에 근거가 된다.

위에서 제시한 공공도서관 $\mathrm{OPAC}$ 인터페이 스의 발전 방안이 구현되기 위해서는 서지레코 드가 우선 완전하게 입력되어야 할 것이다. 설 문조사를 통해서도 인터페이스가 개선되기 위 한 필수사항은 데이터베이스에 자료의 정보에 대한 완전한 입력이 가장 높은 응답으로 나타났 다. 현재 $\mathrm{OPAC}$ 에서 제공하는 주제어 및 목차. 초록, 이용대상과 같은 정보에 대한 만족도도 매우 낮게 나타났다. 서지레코드의 완전한 입력 은 위에서 나열한 다양한 $\mathrm{OPAC}$ 의 기능을 구현 할 수 있는 토대가 될 것이며, 이를 통해 이용자 의 $\mathrm{OPAC}$ 에 대한 만족도가 높아질 것이다.

이 연구는 사례분석과 설문조사 결과를 바탕 으로 공공도서관 $\mathrm{OPAC}$ 인터페이스의 발전방 안을 제시했다는데 의의가 있다. 그러나 향후 사례분석을 위한 표본의 확대가 필요하고, 설문 조사에서 공공도서관의 다양한 이용자의 요구, 예컨대 어린이와 노인, 다문화 이용자의 요구 분석 및 이용수준에 대한 추가적인 보안이 필 요하다. 또한 인터페이스의 실제적인 구현을 위 한 문제를 검토할 필요가 있다.

\section{참 고 문 헌}

경기도사이버도서관홈페이지. [cited 2012.11.16]. $\langle\mathrm{http}$ ://www.golibrary.go.kr/〉. 구중억, 곽승진. 2007. 차세대 OPAC 인터페이 스 기능에 관한 연구.『한국비블리아학
회지』, 18(2): 61-88.

구중억, 이응봉. 2006. Open API 기반 OPAC 2.0 서비스 구현 및 유용성에 관한 연구. 『한국문헌정보학회지』, 40(2): 315-332. 
국가통계시스템. [cited 2012.11.25].

$\langle\mathrm{http}: / / \mathrm{www}$.libsta.go.kr/〉.

국립중앙도서관 도서관연구소. 2011. 도서관용

어해설. 도서관연구소 웹진, 70. [cited 2013.3.16].

〈http://webzine.nl.go.kr/publish/krili /201102_01/pdf/word_0222.pdf $\rangle$.

김선호. 2003. 공공도서관의 노인용 인터페이스 디자인에 관한 연구.『한국도서관 - 정보 학회지』, 34(3): 111-124.

김예린. 2012. 『대학도서관의 OPAC 2.0 기능

의 평가체크리스트 개발』. 석사학위논문. 동의대학교 대학원, 문헌정보학과.

김태승, 이동규. 2005. 전문대학 도서관 이용자들

의 웹 기반 $\mathrm{OPAC}$ 이용실태에 관한 연구.

『한국정보관리학회지』, 22(4): 79-95. 김혜주. 2007. 어린이 도서관의 검색 인터페이

스 디자인에 관한 연구. 『한국비블리아 학회지』, 18(1): 169-187.

남태우, 김창하. 2007. 『목록법이론』. 대구: 태 일사.

대전한밭도서관홈페이지. [cited 2012.11.16].

$\langle\mathrm{http}: / / w w w . h a n b a t l i b r a r y . k r /\rangle$.

사공복희. 2012. 어린이도서관 온라인목록의 인 터페이스 분석. 『정보관리학회지』, 29(1): 63-14.

심경. 2008a. 차세대 도서관 목록. 『도서관문화』, 49(9): 22-28.

심경. 2008b. 차세대 도서관 목록의 사례: AquaBrowser. "도서관문화』, 49(10): 48-56.

심경. 2008c. 차세대 도서관 목록의 사례: WorldCat Local. 『도서관문화』, 49(11):
$54-61$.

유영준. 2011. 차세대 도서관 목록에의 패싯 내비 게이션에 관한 연구.『정보관리학회지』, 28(3): 13-58.

유재옥. 2000. 온라인목록 사용자 인터페이스 에 관한 연구: 탐색실패요인을 중심으로. 『한국정보관리학회지』, 17(2): 139-153. 윤정옥. 2006. 우리나라 공공도서관 어린이용 $\mathrm{OPAC}$ 디스플레이의 분석. 『한국도서 관·정보학회지』, 37(2): 317-343.

윤정옥. 2010. 차세대 도서관 목록 사례의 고찰.

『한국도서관·정보학회지』, 41(1): 5-24. 윤정옥. 2012. 차세대 도서관 목록의 이용자 서 평에 관한 고찰. 『한국도서관 - 정보학회 지』, 46(2): 115-132.

이지원. 2010. 서지네트워크의 웹 이용자 서비 스 연구.『한국비블리아학회지』, 21(1): 5-17.

이현실. 2010. 툴바 제공에 의한 인터넷과 $\mathrm{OPAC}$ 의 이용자 평가 비교연구. 『한국비블리아 학회』, 21(2): 145-157.

이혜영. 2012. 대학도서관의 OPAC 2.0 서비스에 대한 이용자 인식 조사. 『한국도서관 · 정 보학회지』, 43(2): 179-201.

전북도청도서관. [cited 2012.11.16]. 〈http://library.jeonbuk.go.kr/main/ main.php〉.

채현수, 이지연. 2012. 대학 강의지원시스템 이 용성 향상을 위한 이용자 인터페이스 설 계 원칙 개발. 『정보관리학회지』, 29(3): 123-144.

청주시립정보도서관. [cited 2012.11.16]. 〈http://www.cjcil.com/main.asp〉. 
충북 중앙도서관. [cited 2012.11.16].

〈http://www.cbjalib.go.kr/index.sko〉. 한국도서관협회. 2010.『문헌정보학용어사전』. 개정판. 서울: 동협회.

Biblionix. [cited 2012.11.16]. 〈http://www.biblionix.com〉.

Breeding, Marshall. 2007. "Introduction." Library Technology Reports, 43(3): 5-14.

Breeding, Marshall. 2012. "Automation marketplace 2012: Agents of Change." Library Journal. [online]. [cited 2012.11.16]. 〈http://1j.libraryjournal.com/2012/03 /industry-news/automation-marketp lace-2012-agents-of-change/ $>$.

Breeding, Marshall and Andromeda Yelton. 2011. 'Librarians' Assessments of Automation Systems: Survey Results 2007-2010." Library Technology Reports, $47(4): 12-18$.

ByWater Solution. [cited 2012.11.16]. 〈http://www.bywatersolutions.com〉.

Chalon, Patrice, Emmanuel Di Pretoro, and Laurece Kohn. 2008. "OPAC 2.0 Opportunities, development and analysis." In 11th European Conference of Medical and Health Libraries, 1-14.

Columbia County Rural Library District. [cited 2012.11.16].

〈http://www.ccrld.lib.wa.us/index.php〉.

County of Los Angeles Public Library. [cited 2012.11.16].

$\langle$ http://www.colapublib.org/〉.

Henderson Library. [cited 2012.11.16]. $\langle$ http://www.mypubliclibrary.com/c atalog/ $>$.

Library Corporation. [cited 2012.11.16].

$\langle$ http://www.TLCdelivers.com〉.

LOS ANGELES Public Library. [cited 2012. 11.16].

$\langle$ http://www.lapl.org/catalog/〉.

Marcin, Susan and Peter Morris. 2008. "OPAC: The Next Generation Placing an Encore Front End onto a SirsiDynix ILS." Computers in Libraries, 28(5): 6-9.

Pace, Andrew K. 2007. "Users and Uses of Bibliographic Data: The Promise and Paradox of Bibliographic Control." [cited 2012.11.10]. $\langle$ http://www.lib.ncsu.edu/endeca/pr esentations/20070308-fbc-pace.ppt $\rangle$.

Patten, David. 2007. "Are you happy with your Opac?" Library \& Information Update, 6(10): 32-34.

Polaris Library System. [cited 2012.11.16]. 〈http://www.polarislibrary.com〉.

Sirsidynix. [cited 2012.11.16]. $\langle$ http://www.sirsidynix.com〉.

Tam, W., A. M. Cox, and A. Bussey. 2009. "Student user preferences for features of next-generation OPACs: a case study of University of Sheffield international students." Program: electronic library and information systems, 43(4): 349-374.

Vinita Public Library. [cited 2012.11.16]. 〈https://vinita.biblionix.com/atoz/ca 
talog/?advanced $=1\rangle$.

Wilson, Katie. 2007. OPAC 2.0: Next generation online library catalogues ride the web 2.0 wave. [online]. [cited 2012. 11.10].

〈http://epubs.scu.edu.au/cgi/viewco ntent. . gi? article $=1010 \&$ contex $=$ lib pubs $>$.

Yang, Sharon Q. and Melissa A. Hofmann. 2011. "Next generation or current generation?: A study of the OPACs of 260 academic libraries in the USA and Canada." Library Hi Tech, 29(2): 266-300. 